\title{
PARKFIELD, CALIFORNIA, EARTHQUAKE OF JUNE 1966: INTERPRETATION OF THE STRONG MOTION RECORDS
}

\author{
JAFAR SHOJA-TAHERI \\ Seismographic Station, Department of Geology and Geophysics, University of California, Berkeley, California, U.S.A.*
}

\begin{abstract}
SUMMARY
A detailed seismological interpretation of the strong motion records was attempted for the 1966 Parkfield earthquake, California. Velocity and displacement traces integrated from the corresponding recorded accelerograms were found most valuable in studying the earthquake mechanism and wave forms. A double-couple right-lateral strike - slip mechanism (along the San Andreas fault) is consistent with the recorded direct S-waves originating from the hypocentre. High energy arrivals observed on the velocity traces are interpreted as S-waves ('stopping phases') that originated at the termination of the rupture towards the south-east of the San Andreas fault. A double-couple left-lateral strike-slip mechanism is suggested as the cause of this rupture termination.

From particle velocity diagrams of the stopping phases in the horizontal plane, the rupture length was found to be between 20 and $28 \mathrm{~km}$. Corresponding rupture velocities are estimated to be $2.5 \pm 0.1$ and $3.1 \pm 0.5 \mathrm{~km} / \mathrm{s}$. The inference from the strong motion records is that Love waves were more excited at the south-western than the north-eastern side of the fault, whereas the Rayleigh waves were more energetic at the north-eastern than the south-western side of the fault.
\end{abstract}

\section{INTRODUCTION}

A theoretical explanation of the behaviour of earthquakes near the sources of energy release (a rupturing fault) is among the most important problems in seismology and has recently attracted the attention of many investigators in this field..$^{1-6}$ The present scarcity of strong ground motion recordings together with the complexities introduced by geological variations and faulting mechanisms limit the observational data which are needed to test the theoretical models. However, the major social concerns regarding the problem of earthquake hazards have led many of the seismic prone countries (e.g. U.S.A., Japan, U.S.S.R., Iran, Turkey) to install more strong motion instruments in active zones. The speedier collection of the strong motion observations together with the development of understanding of the detailed mechanism of earthquakes should lead in the next decade to major advances in strong motion seismology.

The present study, aimed at a better understanding of energy release and source mechanism, is an analysis of strong motion records of the Parkfield 1966 earthquake. An attempt is made in what follows to interpret these records in terms of a simple model of faulting ${ }^{4,5,7}$ and elementary seismic wave theory. The results have engineering implications for design near faults. ${ }^{8}$

\section{BACKGROUND}

The main shock $\left(M_{\mathrm{L}}=5 \cdot 5, m_{\mathrm{b}}=5 \cdot 8, M_{\mathrm{s}}=6 \cdot 4\right)$ occurred on 27 June 1966 at $9: 26$ p.m. Pacific Daylight Time (04:26:13.4 GMT, 28 June 1966) following two light foreshocks (magnitudes 2-3) at 6:00 p.m. and $6: 15$ p.m., and a stronger foreshock of magnitude $5 \cdot 1$ at $9: 09$ p.m. on 27 June. ${ }^{9}$ The co-ordinates of the origin of the main shock were found to be $35^{\circ} 57^{\prime} \cdot 3 \mathrm{~N}$ and $120^{\circ} 29^{\prime} .9 \mathrm{~W}$ (see Figure 1). This earthquake was followed by a large number of aftershocks for several weeks. ${ }^{10}$

\footnotetext{
* On leave from Geophysics Department, School of Sciences, Ferdowsi University, Mashad, Iran.

0098-8847/80/0608-0527\$01.00

(C) 1980 by John Wiley \& Sons, Ltd.

Received 1 October 1979

Revised 23 April 1980
} 


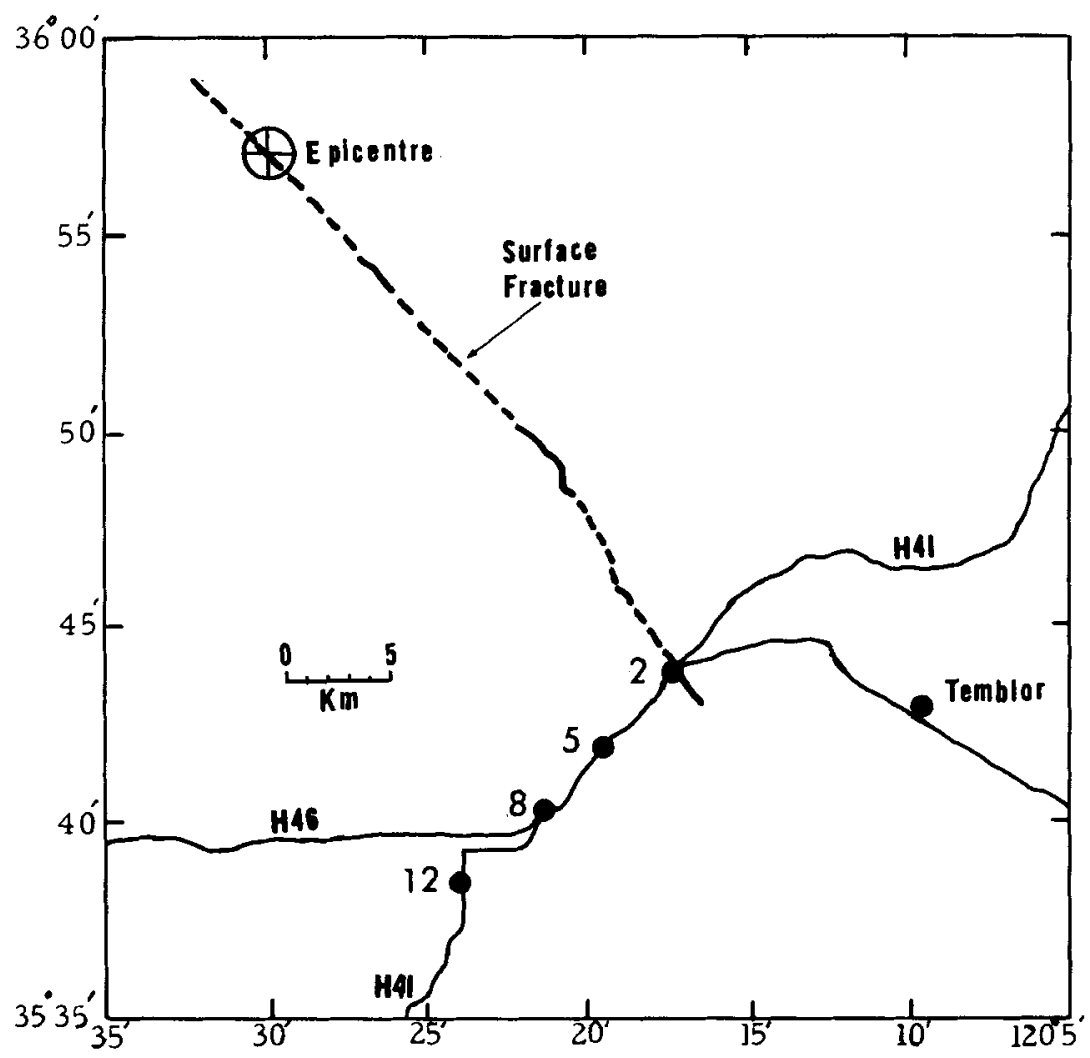

Figure 1. Map showing the epicentre of the Parkfield earthquake, the fault zone and locations of accelerographs

The first field observation made along the San Andreas fault zone early the morning after the main shock ${ }^{11}$ indicated that the white line on Highway 46 (see Figure 1) at its intersection with the fault zone had been offset by $4.5 \mathrm{~cm}$ in the right lateral sense. But extrapolation of the offset curve back to the origin time of the main shock indicates that there was essentially no surface fault offset at the time of the main shock. ${ }^{12}$

On the basis of en echelon cracks exposed on the surface, the rupture length along the San Andreas fault may be estimated to be about $33 \mathrm{~km}$ (see Figure 1). The overall distribution of the aftershocks, however, suggests a surface length of $27 \mathrm{~km} .^{13}$

The accelerographs at Cholame, approximately $30 \mathrm{~km}$ south-east along the fault trace from the epicentre, recorded several aftershocks during the first few minutes after the main shock. ${ }^{14}$ The $\mathrm{S}$ minus $\mathrm{P}$ of these events decreased from about $5 \mathrm{~s}$ for the main shock to about $2 \mathrm{~s}$ or less for the aftershocks. This decrease indicates a smaller focal distance and hence that the fault propagated south-eastward from the epicentre for a distance of about $20 \mathrm{~km}$.

Eaton et $a l^{10}$ made a detailed analysis of the aftershocks which occurred between the third and the eightysecond day following the main shock. Using 474 well-located aftershocks, they found the strike and dip of the fault plane to be $\mathrm{N} 39 \mathrm{~W}$ and $\mathrm{S} 86 \mathrm{~W}$, respectively. Over 95 per cent of these aftershocks had focal depths between 1 and $12 \mathrm{~km}$, and none had a focal depth greater than $15 \mathrm{~km}$. The foci of these aftershocks were highly concentrated between 2 and $4 \mathrm{~km}$ and also between 8 and $10 \mathrm{~km}$.

The aftershocks south of $35^{\circ} 50^{\prime} \mathrm{N}$ (see Table II of Eaton et al ${ }^{10}$ ) show the highest concentration between $35^{\circ} 47^{\prime} \cdot 5 \mathrm{~N}$ and $35^{\circ} 48^{\prime} \cdot 5 \mathrm{~N}$ (see Figure 1). Based on the P-wave polarities for the main shock, McEvilly et al ${ }^{13}$ evaluated that the strike and dip angles range from N35W to $\mathrm{N} 24 \mathrm{~W}$ and $\mathrm{N} 88 \mathrm{E}$ to S85W, respectively.

Eaton ${ }^{15}$ estimated the rupture velocity to be $2.2 \mathrm{~km} / \mathrm{s}$ by using the motion of a radio time recorder operated about $20 \mathrm{~km}$ down the fault from the epicentre. In addition, zeros of spectra from Love waves recorded at Berkeley were found to be consistent with this rupture velocity. ${ }^{16}$ 
Interpretation of the mechanism of the main shock by comparing observed and synthesized strong ground motion records has been carried out already by a number of investigators. ${ }^{1,2,17-19}$ None of the studies provides an explanation that is convincing in all aspects. A recent investigation was made by Trifunac et $\mathrm{al}^{6}$ by fitting a moving dislocation model to strong motion data obtained from five stations. The preferred model (also consistent with geodetic data and fault creep measurements) has a zone of significant faulting about $20 \mathrm{~km}$ long in the northern section of the fault with a rupture velocity between 2.4 and $2.5 \mathrm{~km} / \mathrm{s}$ and a dislocation amplitude of $120 \mathrm{~cm}$.

Eaton et $a l^{10}$ have now conducted several short but detailed refraction profiles in the Parkfield-Cholame region to determine the structure in the upper crust. The P-wave velocities of the upper $15 \mathrm{~km}$ of the crust for south-western and north-eastern sides of the fault are shown in Table I.

Table I. Crustal model along the San Andreas fault in the Parkfield-Cholame region (Eaton et al $^{10}$ )

\begin{tabular}{cccc}
\hline SW & \multicolumn{2}{c}{$\mathrm{NE}$} \\
$(\mathrm{km})$ & $(\mathrm{km} / \mathrm{s})$ & $(\mathrm{km})$ & $(\mathrm{km} / \mathrm{s})$ \\
\hline $0-0.28$ & 1.70 & $0-0.18$ & 2.36 \\
$0.28-1.55$ & $2 \cdot 80$ & $0.18-1.24$ & 3.34 \\
$1.55-3.74$ & 5.00 & $1.24-2.76$ & 4.62 \\
$3.74-15.00$ & 6.00 & $2.76-4.40$ & 5.62 \\
& & $4 \cdot 40-15.00$ & 6.00 \\
\hline
\end{tabular}

\section{INTERPRETATION OF THE STRONG MOTION RECORDINGS}

In the present section, the main shock of the Parkfield 1966 earthquake is analysed by interpreting the recorded strong ground motion recordings using standard seismological theory on seismic waves; ray arguments are supplied to infer the rupture velocity during this earthquake. Further information on the source mechanism is drawn from studies of projections of particle velocities of the ground on the horizontal plane.

The particle velocity traces have been chosen as the fundamental data against which the model of faulting is tested. The acceleration traces contain more information (because of higher frequency content), but they are very sensitive to minor details of faulting, geological heterogeneities and surface topography. Furthermore, current theoretical models of source mechanisms ${ }^{20}$ suggest that, in the near-field, particle velocity amplitude is directly proportional to the driving stress at the fault.

Displacement traces are used as supplementary data to test the gross features of the fault model inferred by the velocity traces and also to study the recorded surface waves.

For modelling purposes, it is desirable to rotate the horizontal particle velocities and displacements into a co-ordinate system which corresponds to the components parallel and normal to the fault. The directions of $\mathrm{S} 33 \mathrm{E}$ and $\mathrm{N} 57 \mathrm{E}$ are chosen ${ }^{13}$ as the parallel and normal components to the fault. The fault plane is taken vertical. The recorded horizontal components of velocity and displacement of all sites, except $\mathrm{CH} \$ 2$ where only one horizontal component was recorded during the earthquake, were all rotated to the chosen coordinate system.

To convert the instrumentally recorded traces to the actual ground motions, all vertical and horizontal components (both velocity and displacement) were reversed. These records are shown in Figures 2(a), 3(a), 4(a), $5(a)$ and 6(a) respectively.

In order to enhance the extractable information of fault mechanisms, the velocity components were both high-pass and low-pass filtered using zero phase Butterworth filters with 4 poles and corner frequencies of $3 \mathrm{~Hz}$. The high-pass and low-pass filtered velocity components are shown respectively on the upper and lower halves of Figures 2(b), 3(b), 4(b), 5(b) and 6(b).

Using the crustal P-velocity models given by Eaton et al ${ }^{10}$ (see Table I) for south-west and north-east sides of the fault, the $\mathbf{P}$ and $\mathbf{S}$ travel times to each station were calculated for the main earthquake. The focal depth was taken as $5 \mathrm{~km}$, and Poisson's ratio was assumed to obtain $S$ from $P$ velocities so that $\sigma=0 \cdot 25$. The 


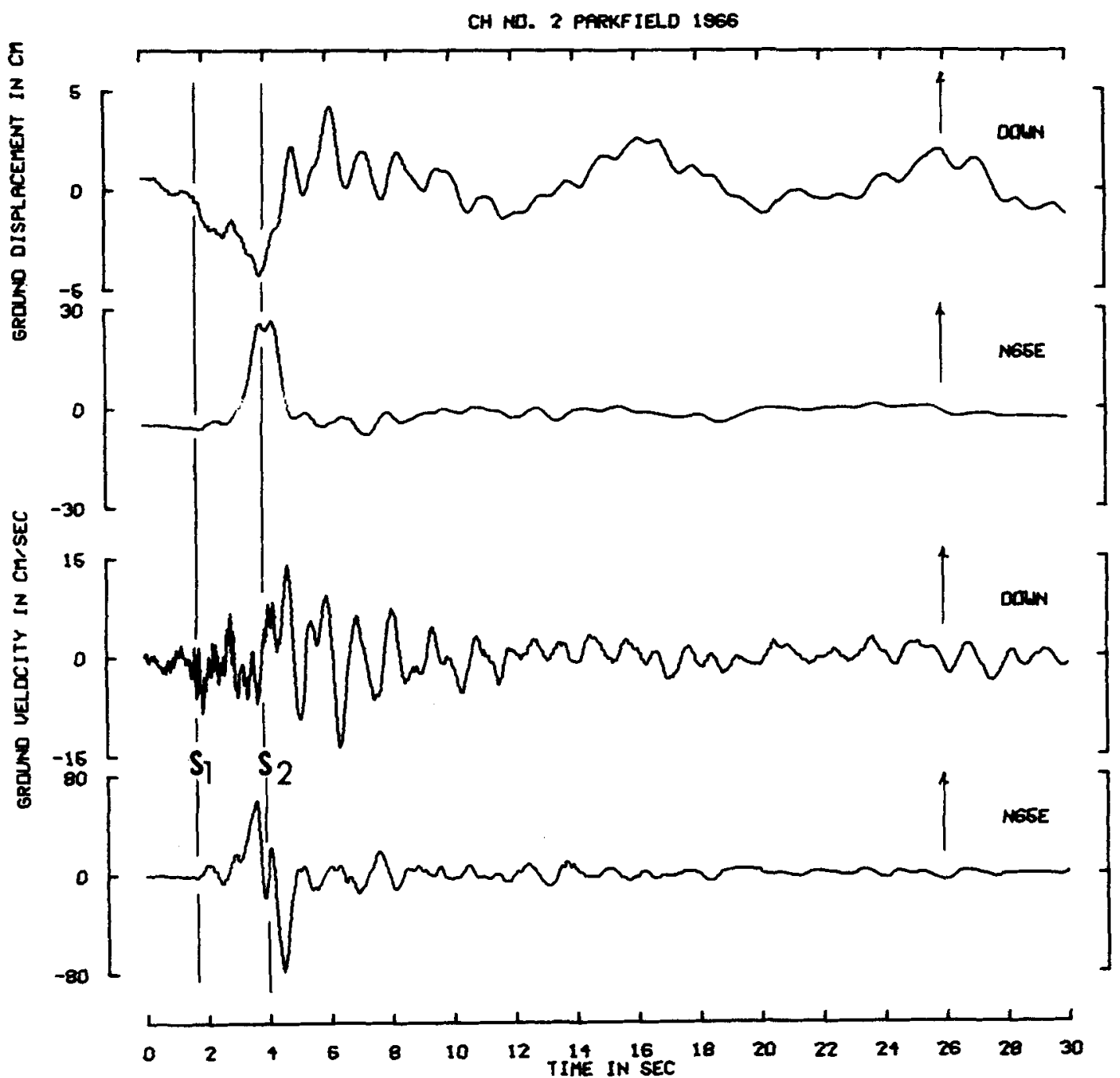

Figure 2(a). Ground displacement and velocity components of the 1966 Parkfield earthquake recorded at $\mathrm{CH} \sharp 2$. The arrows show positive direction of the ground motions

resulting travel times in the upper layers from the source are as follows:

$\begin{array}{cccc}\text { Station } & T_{\mathrm{P}} & T_{\mathrm{S}} & T_{\mathrm{S}-\mathrm{P}} \\ 2 & & (\mathrm{~s}) & \\ 5 & 6.2 & 10 \cdot 7 & 4.5 \\ 8 & 6.3 & 10.8 & 4.6 \\ 12 & 6.6 & 11.4 & 4.8 \\ \text { Temblor } & 6.9 & 12.0 & 5.1 \\ & 7.5 & 13.1 & 5.6\end{array}$

The absolute error may be on the order of $0.2 \mathrm{~s}$, judging from the standard errors in calculated origin times given for the aftershocks in Eaton et al. ${ }^{10}$ The average $P$ velocities, for the main shock, resulting from the given crustal models, are as follows: $5.73 \mathrm{~km} / \mathrm{s}$ to station $2,5.74 \mathrm{~km} / \mathrm{s}$ to station $5,5.74 \mathrm{~km} / \mathrm{s}$ to station $8,5.76 \mathrm{~km} / \mathrm{s}$ to station 12 and $5.69 \mathrm{~km} / \mathrm{s}$ to station Temblor.

The pendulum starter at station 5 was nearly in contact so that the accelerograph operated immediately after the calculated P-wave arrived. 
CH ND. 2 PARKF IELD 1966

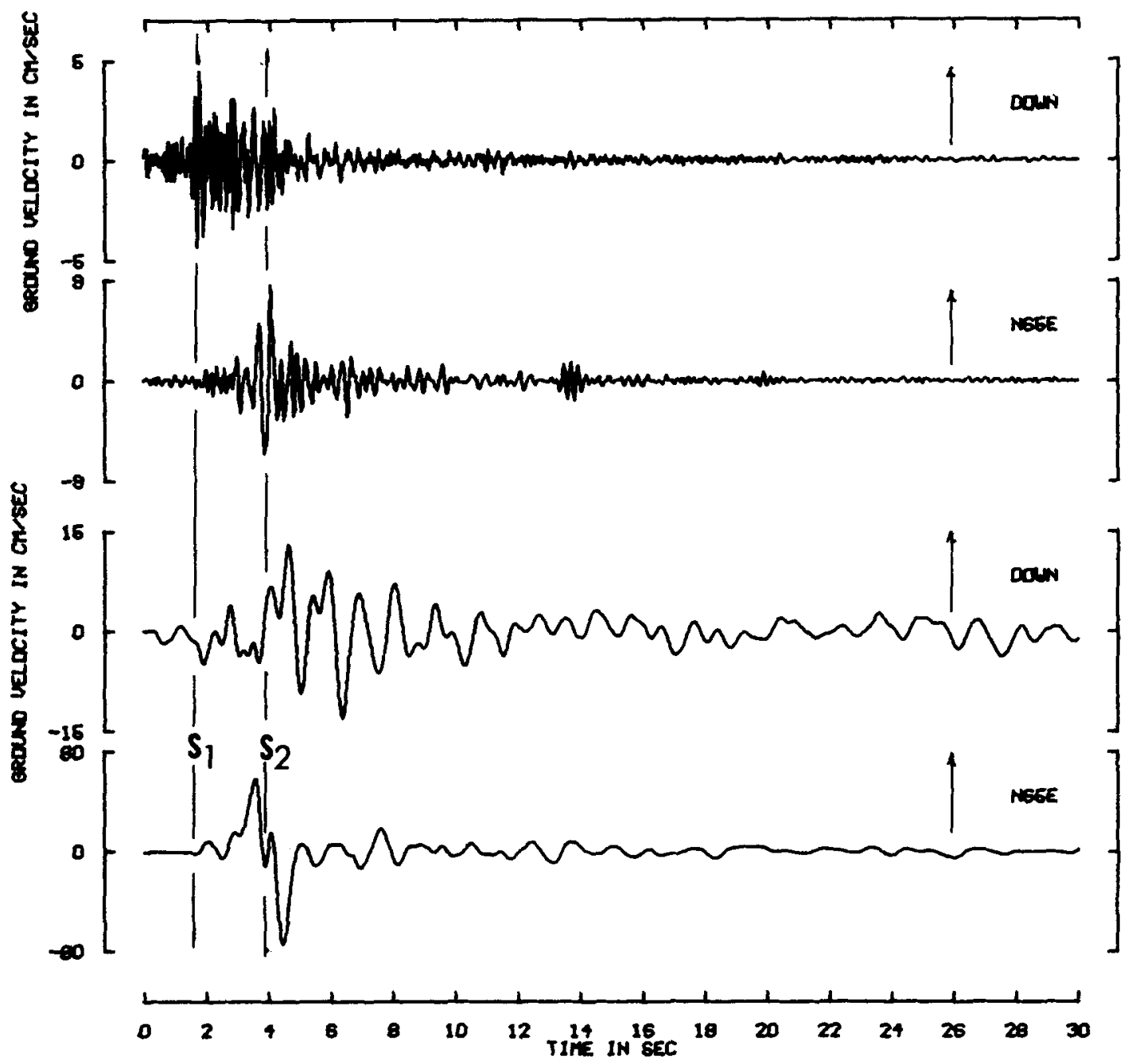

Figure 2(b). High-pass and low-pass filtered ground velocity components of the 1966 Parkfield earthquake recorded at $\mathrm{CH} \sharp 2$. The arrows show positive direction of the ground motions

The observed arrival of the direct S-wave at each station is shown by $S_{1}$ [Figure 2(a), (b) to Figure 6(a), (b)]. Amplitudes as well as polarizations of $S_{1}$ in velocity components provide clear information on fault mechanism during the main shock. At all stations (except $\mathrm{CH} \# 2$ where the parallel component was not recorded) the velocity amplitudes on normal components N57E are larger than those for parallel components S33E. This is expected (because the epicentral distances, varying between 30 and $40 \mathrm{~km}$, are relatively larger than the fault distances which vary between $80 \mathrm{~m}$, for $\mathrm{CH} \# 2$, and about $15 \mathrm{~km}$ for $\mathrm{CH} \# 12$; see Figure 1) from the radiation pattern of a double-couple source. ${ }^{2,5,21}$ Polarization and amplitude of horizontal and vertical components at $\mathrm{CH} \# 5,8,12$ [see Figures $3(\mathrm{~b}), 4(\mathrm{~b})$ and $5(\mathrm{~b})$ ], which are on the SW side of the fault, generally indicate that the main shock at the epicentre had double-couple right-lateral strike-slip mechanism. At Temblor, which is on the north-eastern side of the fault, the polarization of the S-wave on N57E [see Figure 6(b)] confirms the inferred mechanism by $\mathrm{CH} \# 5,8,12$. But the polarization on the vertical and S33E does not agree with this simple mechanism model. It should be noticed, however, that because the angle of epicentral azimuth of this station, with respect to the strike of the fault is small ${ }^{21}$ (about 10 degrees), the polarization of the S-wave on these components becomes quite sensitive (because of small amplitudes) to the details of faulting at the hypocentre, to the geological heterogeneities along the ray path, and so on. 
CH ND. 5 PAREKFIELD IS66

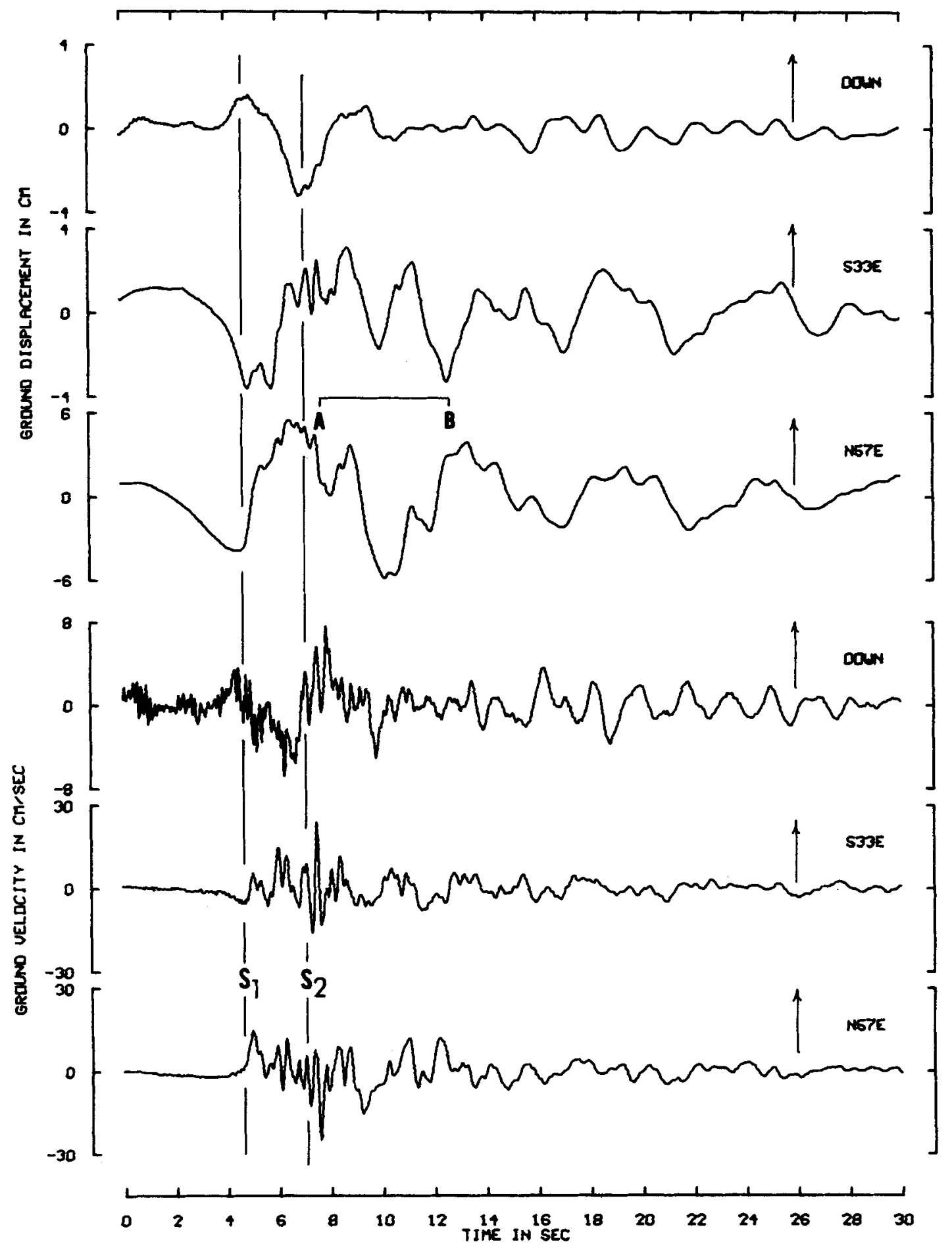

Figure 3(a). Ground displacement and velocity components of the 1966 Parkfield earthquake recorded at $\mathrm{CH}$ \#5. The arrows show positive direction of the ground motions 
CH NO. 5 PAREKFIELD 1966

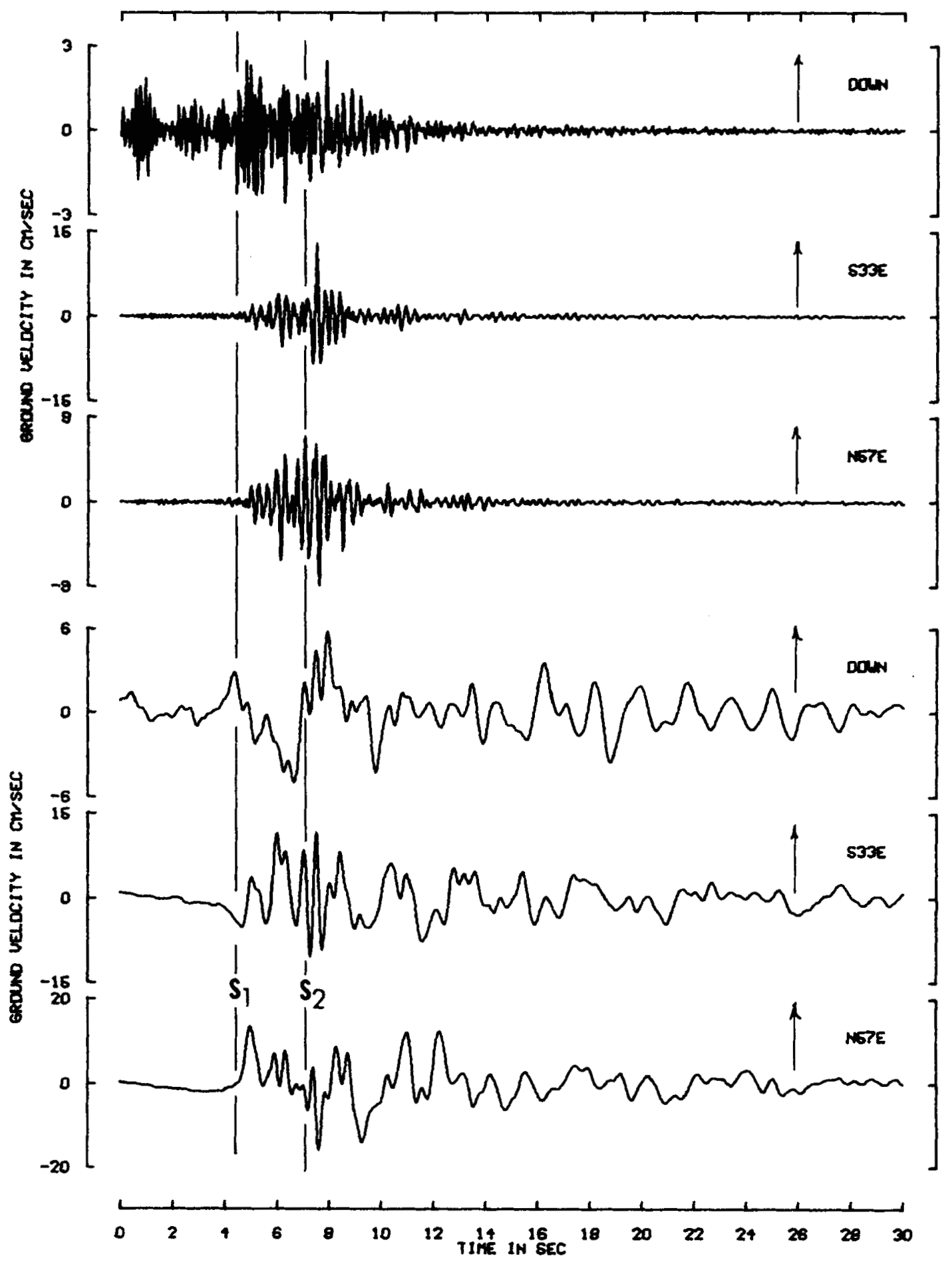

Figure 3(b). High-pass and low-pass filtered ground velocity components of the 1966 Parkfield earthquake recorded at $\mathrm{CH} \# 5$. The arrows show positive direction of the ground motions 


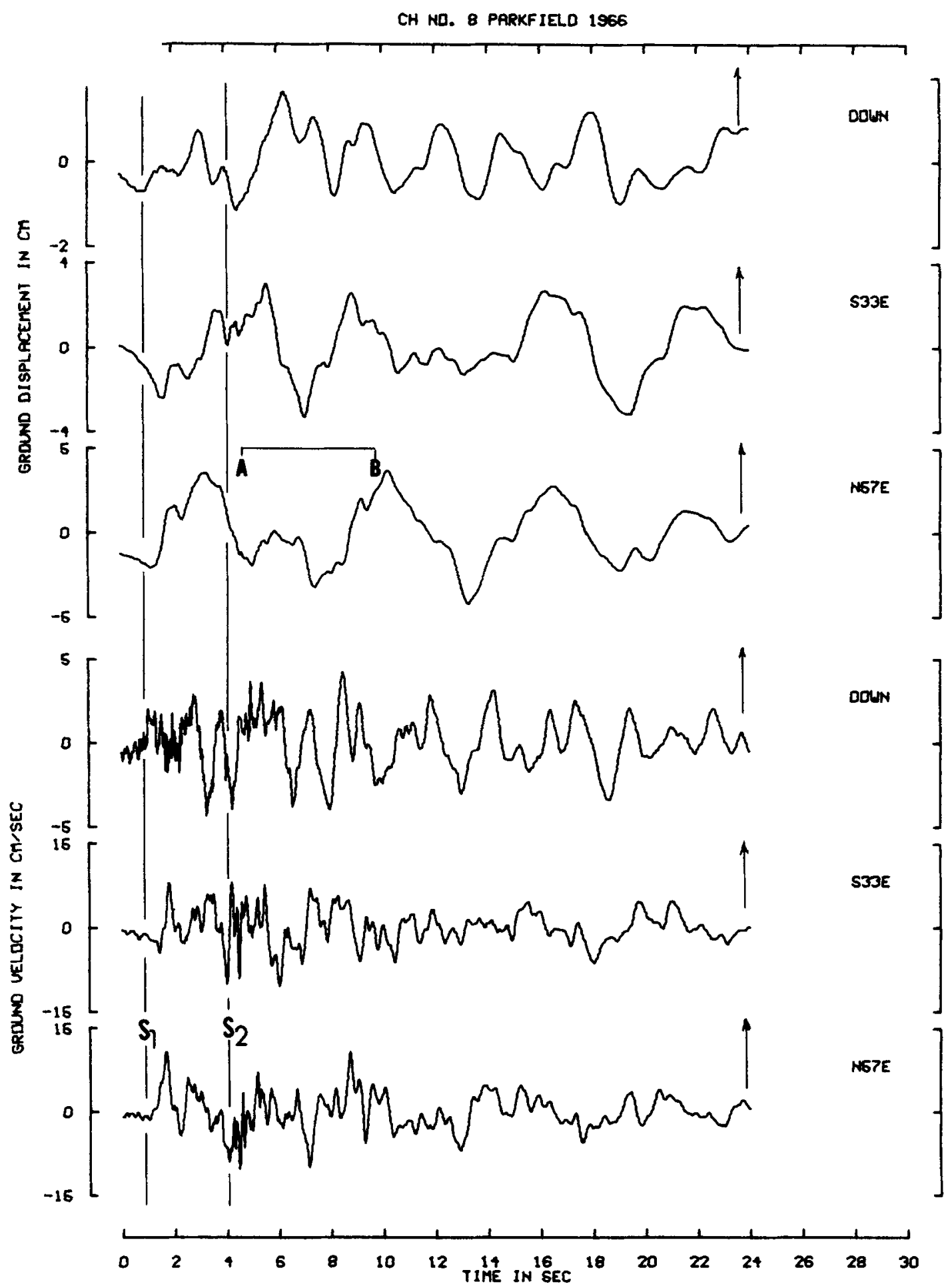

Figure 4(a). Ground displacement and velocity components of the 1966 Parkfield earthquake recorded at CH \#8. The arrows show positive direction of the ground motions 


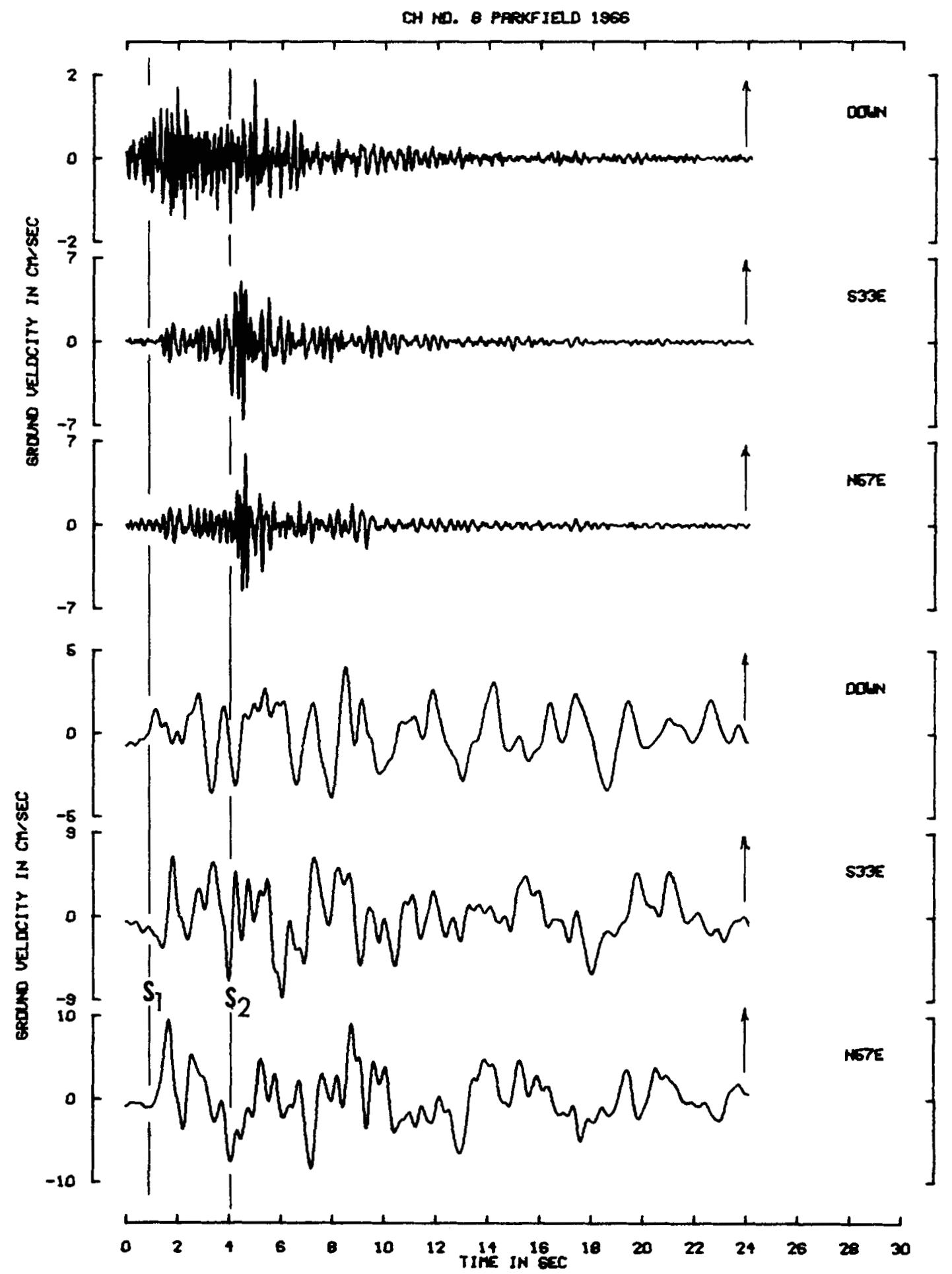

Figure 4(b). High-pass and low-pass filtered ground velocity components of the 1966 Parkfield earthquake recorded at $\mathrm{CH} \$ 8$. The arrows show positive direction of the ground motions 
CH ND. 12 PARKF IELD 1966

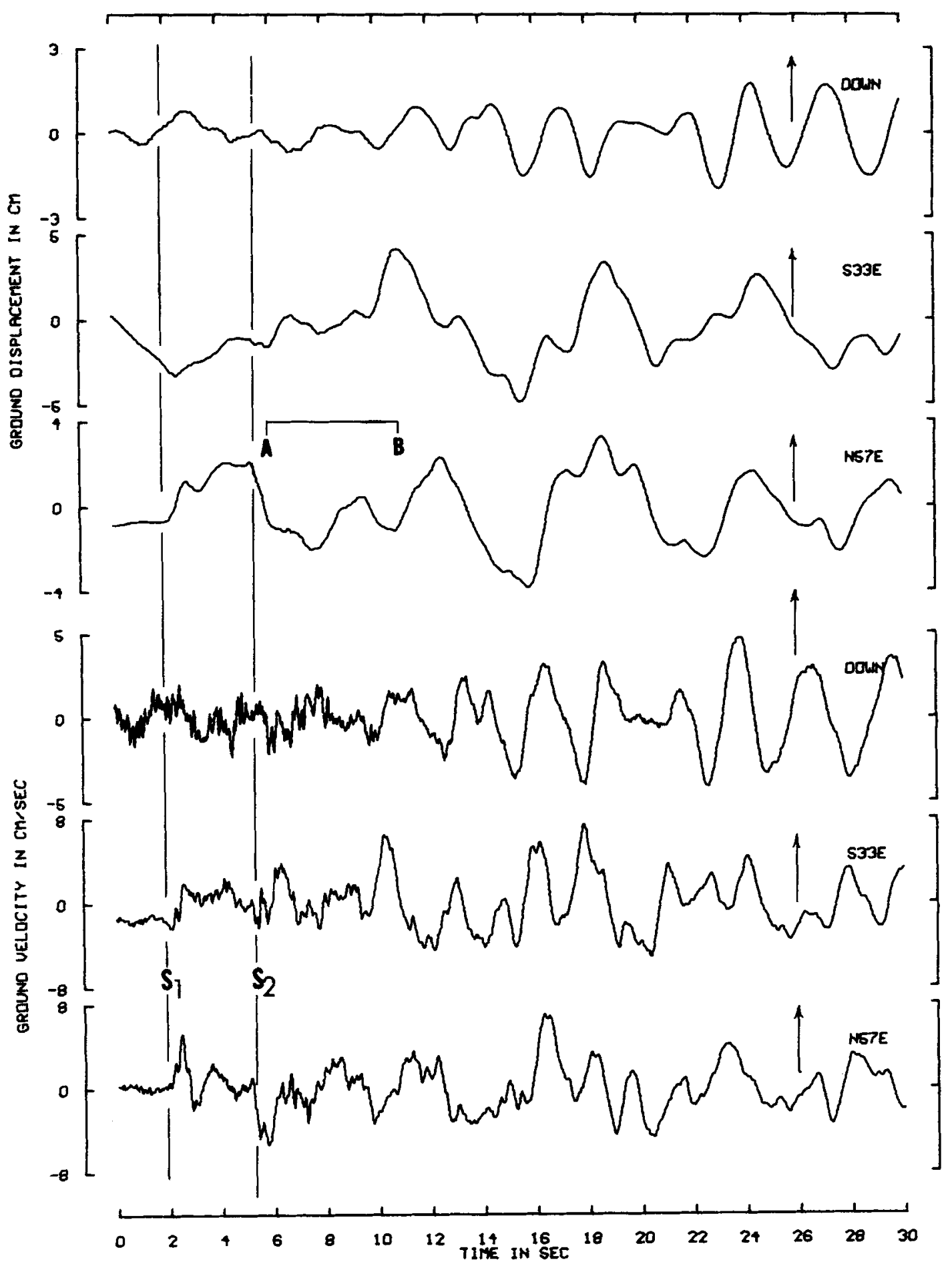

Figure 5(a). Ground displacement and velocity components of the 1966 Parkfield earthquake recorded at $\mathrm{CH} \# 12$. The arrows show positive direction of the ground motions 
CH No. 12 PARKFIED 1566

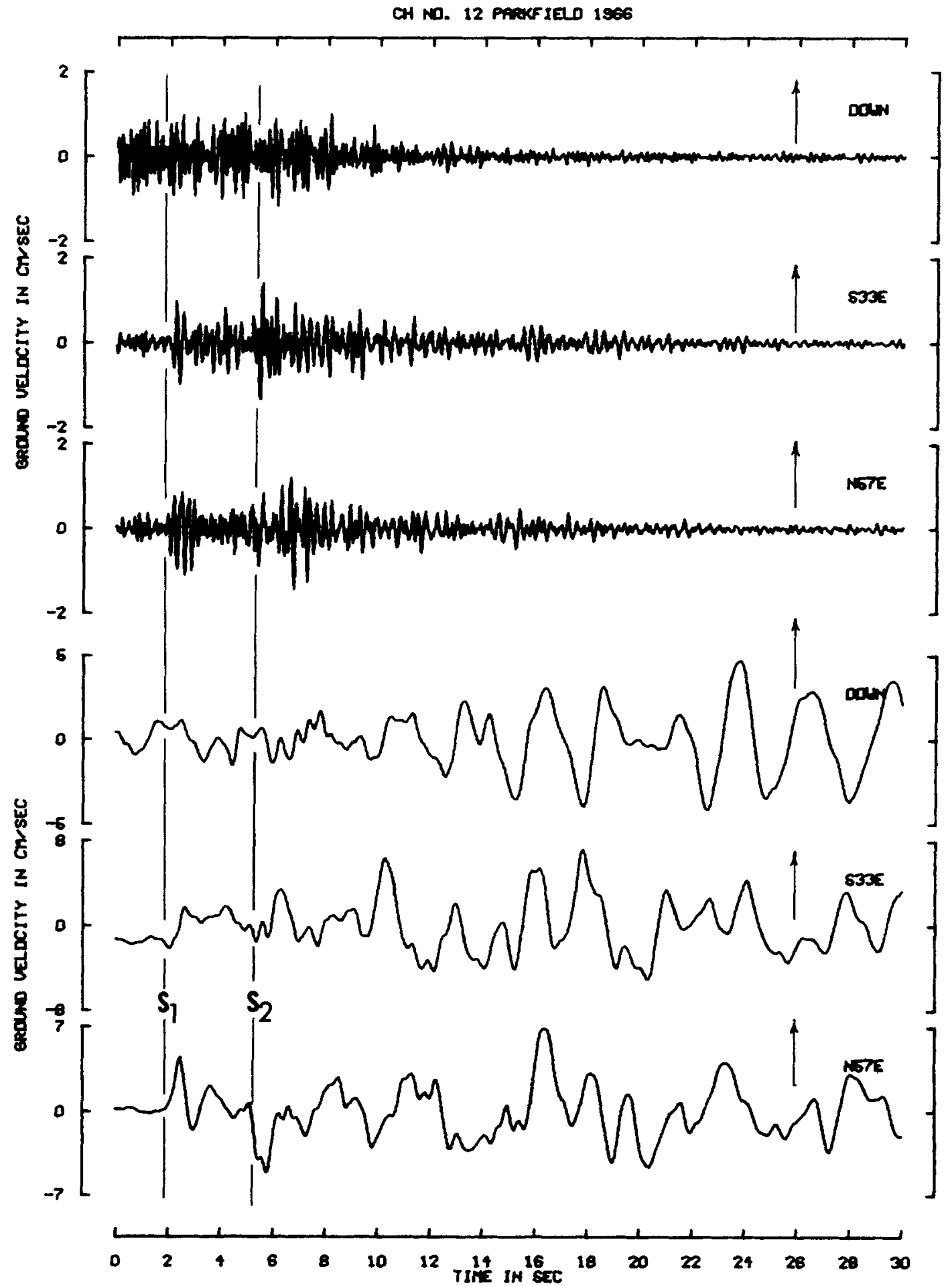

Figure 5(b) High-pass and low-pass filtered ground velocity components of the 1966 Parkfield earthquake recorded at $\mathrm{CH} \# 12$. The arrows show positive direction of the ground motions 


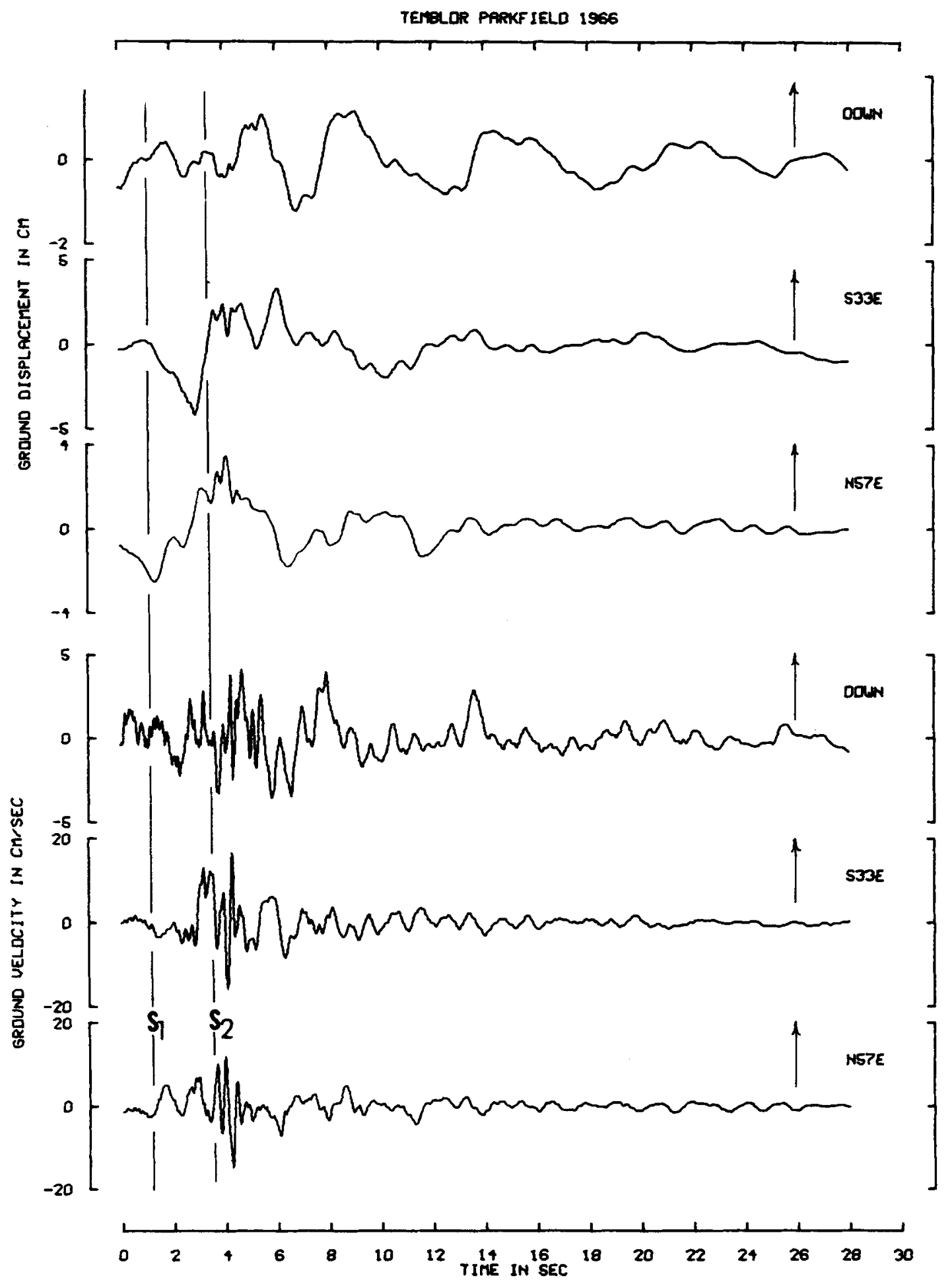

Figure 6(a). Ground displacement and velocity components of the 1966 Parkfield earthquake at Temblor. The arrows show positive direction of the ground motions 


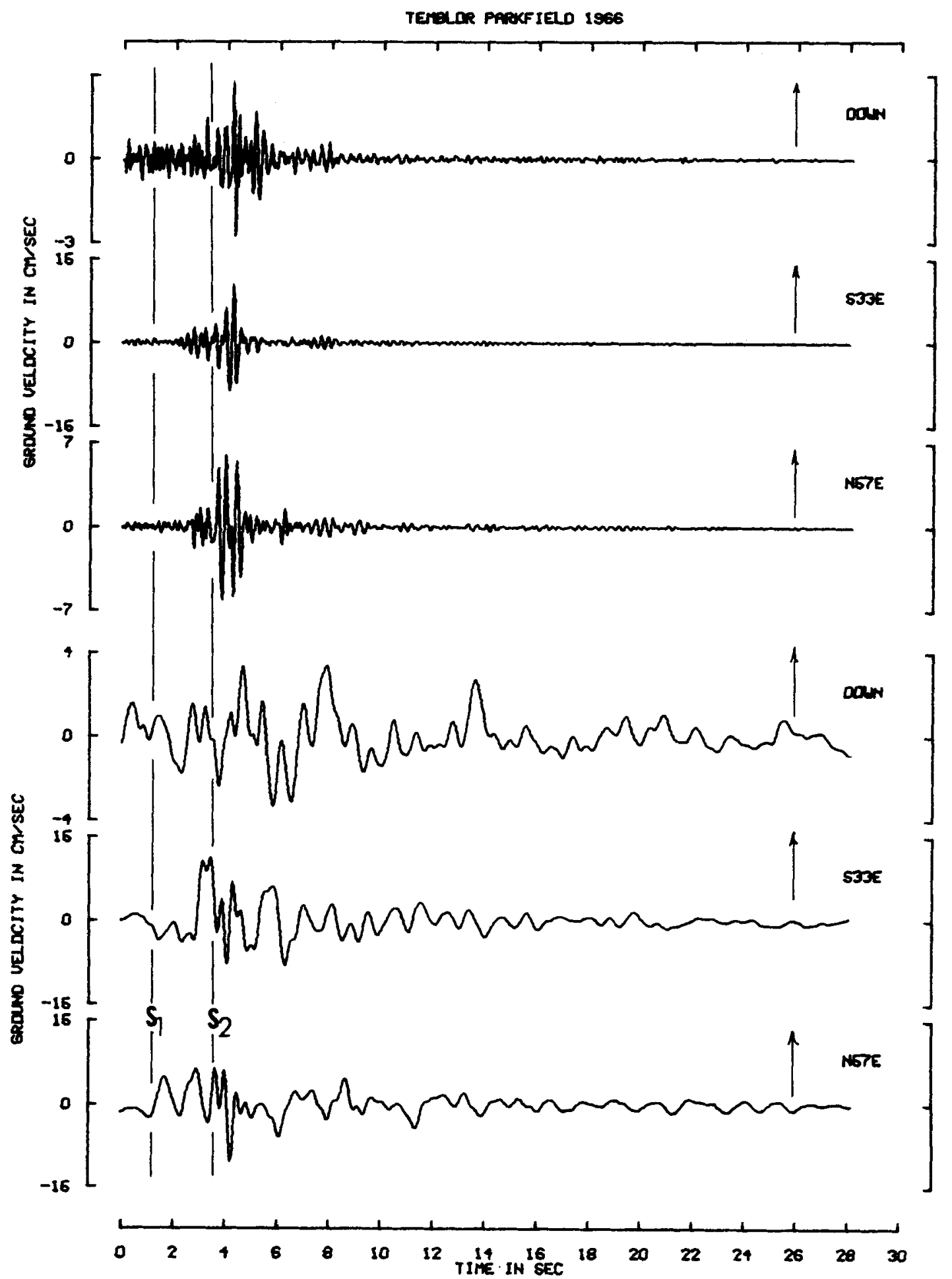

Figure 6(b). High-pass and low-pass filtered ground velocity components of the 1966 Parkfield earthquake recorded at Temblor. The arrows show positive direction of the ground motions 
At $\mathrm{CH} \# 2$, the direction of the S-wave recorded on the S65E component [see Figure 2(b)] confirms the rightlateral direction of the fault, whereas the down component does not imply such interpretation (perhaps for the same reason stated for the Temblor station).

The particle velocity diagrams of the $S$-wave in the horizontal plane, at stations $\mathrm{CH} \sharp 5,8,12$ and Temblor, are drawn in Figure 7. The prograde elliptical patterns shown at $\mathrm{CH} \sharp 5,8,12$ are expected from a doublecouple right-lateral mechanism. The unexpected prograde pattern of Temblor, for such a mechanism, is the

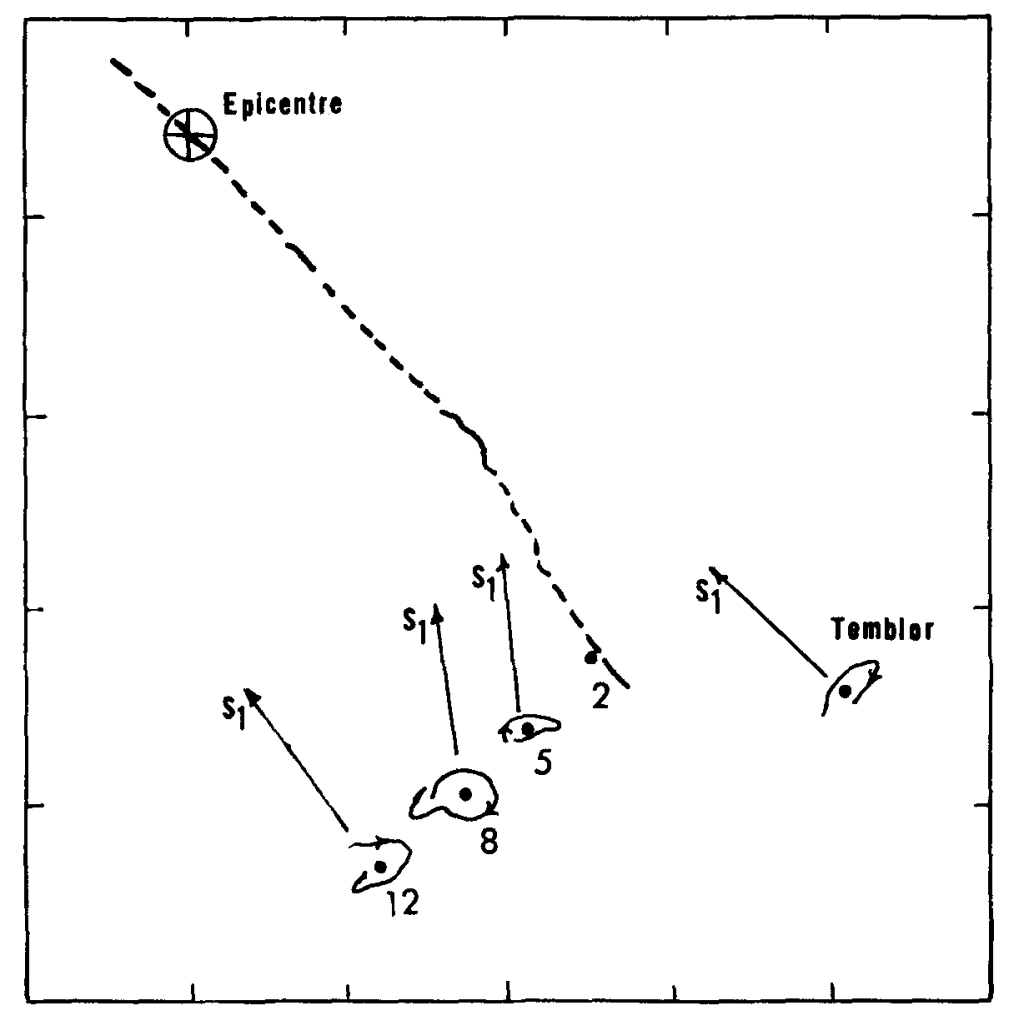

Figure 7. Horizontal S-wave particle velocity diagrams of the Parkfield earthquake at accelerograph stations $\mathrm{CH} \# 5,8,12$ and Temblor

result of polarization change of the S-wave (as discussed before) on the S33E component at this station. The arrows designated by $S_{1}$ are drawn perpendicular to the major axes of the ellipses. In the absence of geological and fault rupture complexities, these arrows would be directed toward the source. While the arrow at Temblor points approximately towards the epicentre, the directions of the arrows at $\mathrm{CH} \$ 5,8,12$ show moderate deviations from the expected directions.

There are two or three onsets shown prior to the arrival of the $S$-wave $\left(\mathbf{S}_{1}\right)$ observed on the high-passed vertical component of velocity at $\mathbf{C H} \$ 5$. These arrivals are probably the $\mathrm{P}$-waves of small earthquakes that occurred immediately (within about $3 \mathrm{~s}$ ) after the main shock of the fractured fault. Since this paper is mainly concerned with study of the gross mechanism of the main shock, these small shocks are not further discussed.

Next, let us consider the onsets designated by $S_{2}$ in Figures 2(a) and 2(b) to Figures 6(a) and 6(b). These onsets are related to the wave with peak accelerations recorded in the corresponding accelerograms. From both engineering and seismological points of view, it is therefore vital to investigate the nature and also the possible generating source of these waves.

These seismic waves are not likely to be predominantly surface waves because they have short durations and non-dispersive features. The amplitudes decrease rather sharply with distance from the source of energy release (compare the amplitudes at $\mathrm{CH} \$ 2,5,8,12$ and Temblor); for surface waves this is not plausible near to 
the source of energy release where production of surface waves should significantly increase with source distance. Furthermore, the arrival times are at least a few seconds earlier than expected if they are assumed to be surface waves (surface waves with such high frequency contents would travel only through a thin section, about $1 \mathrm{~km}$, of the surface with a shear velocity of $1 \mathrm{~km} / \mathrm{s}$ ). The particle velocity diagrams of these waves in the horizontal planes, designated by $S_{2}$, are drawn in Figure 8 . The arrows designated by $S_{2}$ in this figure are drawn perpendicular to the major axes of the ellipses.

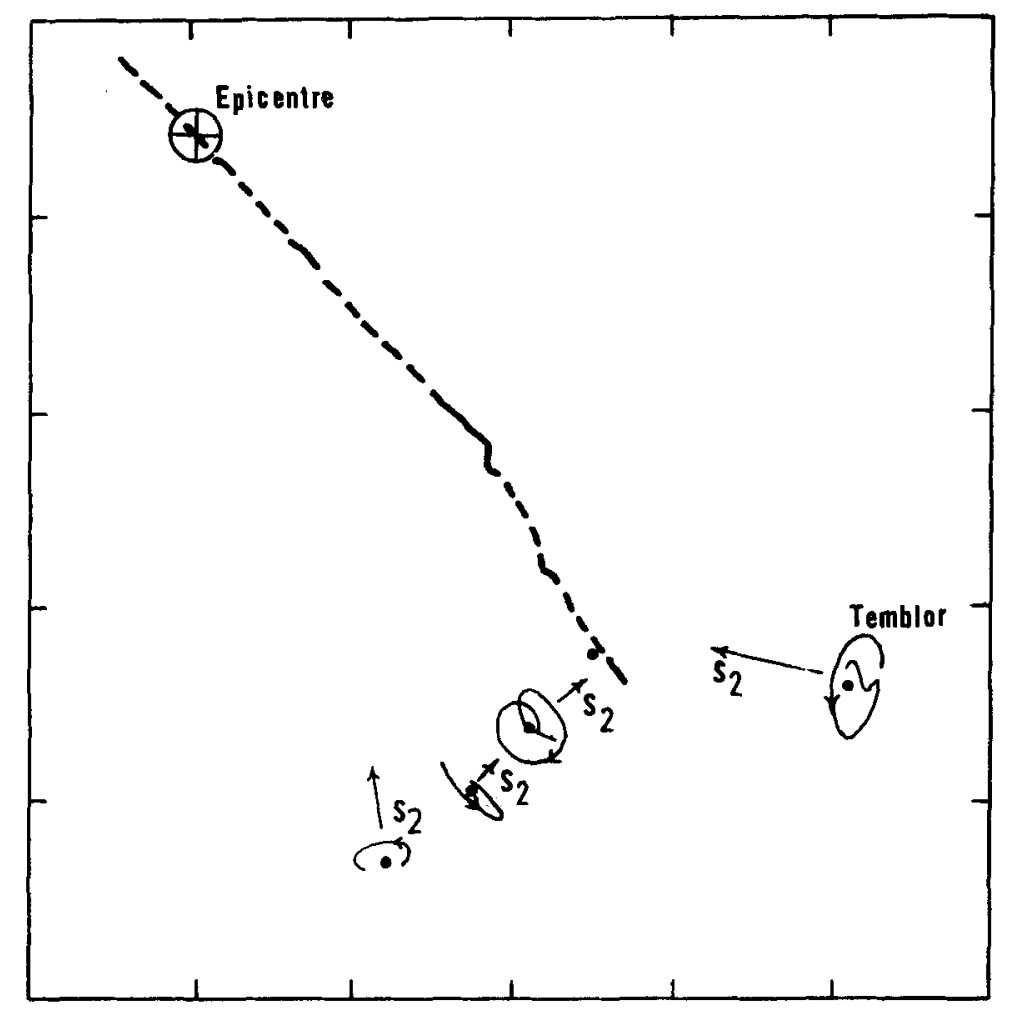

Figure 8. Horizontal particle velocity diagrams of the $\mathrm{S}$-wave originating from termination of rupture during the Parkfield earthquake and recorded at stations $\mathrm{CH} \$ 5,8,12$ and Temblor

The diagrams show that the particle motions of $\mathrm{S}_{2}$-waves at all stations except at $\mathrm{CH} \# 5$ have opposite direction (retrograde) to those of $S_{1}$-waves which originated from the epicentre. It is difficult to infer any particular mechanism for the source of $\mathrm{S}_{2}$-waves from these diagrams. The direction of $\mathrm{S}_{2}$ arrows at $\mathrm{CH} \sharp 5,8$ and Temblor (Figure 8) suggests that the source of these phases is located within a few $\mathrm{km}$ from $\mathrm{CH} ¥ 2$. The displacement $\mathrm{N} 65 \mathrm{E}$ component at $\mathrm{CH} \# 2$ and the displacement $\mathrm{N} 75 \mathrm{E}$ components at $\mathrm{CH} ¥ 5,8,12$ and Temblor [Figures, 2(a), 3(a), 4(a), 5(a) and 6(a)] show that the displacement motions of $\mathrm{S}_{2}$-waves have opposite directions to those of $S_{1}$-waves.

On the basis of these observations, the $S_{2}$-waves are interpreted as $S$-waves generated by termination of the rupture $^{22}$ ('stopping' phases) within a few $\mathrm{km}$ from $\mathrm{CH} \# 2$. A double-couple left-lateral strike-slip is suggested as the cause of this rupture termination.

A reasonable estimate of the location of the end of a fault rupture permits the determination of the average rupture velocity along the fault. From the diagrams of $S_{2}$-waves and the aftershocks distribution, mentioned earlier in this paper, a fault length between 20 and $28 \mathrm{~km}$ may be suggested.

Let us estimate the rupture velocity for two different rupture lengths: $28 \mathrm{~km}$ (which is also confirmed by the diagrams of $\mathrm{S}_{2}$-waves shown in Figure 8 ) and $20 \mathrm{~km}$, respectively. Since the aftershocks at the south-eastern end of the rupture are highly concentrated at focal depths between 2 and $4 \mathrm{~km}$, and also between 8 and 
$10 \mathrm{~km},{ }^{10}$ for each assumed rupture length two different depths of 4 and $8 \mathrm{~km}$ are assigned to the depth at which rupture is terminated. It should be mentioned that because $\mathrm{S}$-wave travel times, from hypocentre to the station, are not too sensitive to variation of focal depth (change of focal depth from 5 to $10 \mathrm{~km}$ introduces only about $0.1 \mathrm{~s}$ variation in the travel times), only one focal depth of $5 \mathrm{~km}$ was assumed in estimation of rupture velocity. Table II shows the rupture velocities, estimated from arrival times of the $S_{1}$ and phases, and their standard deviations. In this table, $L$ is the length assumed for rupture, $H$ is the depth assumed for the termination of

Table II. Estimated rupture velocity, $\sigma$, and the corresponding standard deviation, sd. $L$ and $H$ are, respectively the rupture length and the depth at which rupture is terminated

\begin{tabular}{ccccc}
\hline Case & $\begin{array}{c}L \\
(\mathrm{~km})\end{array}$ & $\begin{array}{c}H \\
(\mathrm{~km})\end{array}$ & $\begin{array}{c}\bar{b} \\
(\mathbf{k m} / \mathbf{s})\end{array}$ & (from five observations) \\
\hline 1 & 28 & 4 & $3 \cdot 13$ & 0.53 \\
2 & 28 & 8 & $3 \cdot 11$ & 0.30 \\
3 & 20 & 4 & $2 \cdot 48$ & 0.11 \\
4 & 20 & 8 & $2 \cdot 42$ & 0.07 \\
\hline
\end{tabular}

rupture, $\bar{b}$ is the average of the rupture velocities estimated from $\mathrm{CH} \sharp 2,5,8,12$ and Temblor records, and sd is the standard deviation of the rupture velocity for one observation.

Cases 1 and 2 with $L=28 \mathrm{~km}$ result in a rupture velocity of about $3 \cdot 1 \mathrm{~km} / \mathrm{s}$ and a relatively large standard deviation between 0.3 and $0.5 \mathrm{~km} / \mathrm{s}$. This velocity is about $0.2 \mathrm{~km} / \mathrm{s}$ smaller than the average shear velocity along the ray paths between the initial source and the stations and about $0.5 \mathrm{~km} / \mathrm{s}$ larger than the average shear velocity along the ray path between the southern end of the rupture and the stations. Cases 3 and 4 with $L=20 \mathrm{~km}$ result, respectively, in rupture velocities of about 2.5 and $2.4 \mathrm{~km} / \mathrm{s}$ with standard deviation of only $0.1 \mathrm{~km} / \mathrm{s}$. These velocities are smaller than average shear velocities in the area.

The small standard error of $0.1 \mathrm{~km} / \mathrm{s}$ of the estimated rupture velocity corresponding to the rupture length of $20 \mathrm{~km}$, together with the high concentration of aftershocks between $33^{\circ} 47^{\prime} .5 \mathrm{~N}$ and $35^{\circ} 48^{\prime} .5 \mathrm{~N}$ (see Table II of Eaton et $^{\mathrm{al}}{ }^{10}$ ) suggest that the fault rupture during the main shock was about $20 \mathrm{~km}$ long. This conclusion is supported by considering the location of the aftershocks which occurred within a few minutes after the main shock.

Let us now consider the recorded surface waves and make some general remarks regarding their existence and their relative features. A significant portion of the total energy which arrived following the stopping phase in Figure 2(a), (b) to 6(a), (b) can be shown to be contributed by surface waves (mainly Love waves because the amplitudes in the horizontal components at each station are, generally, larger than those in the corresponding vertical components). The velocity components carry more detailed and thus less simply interpreted information on the properties of the recorded surface waves than those of corresponding displacement records. For analysis of the gross features of these waves, it is therefore more appropriate to consider the recorded surface waves on displacement records. Love waves dominate the remaining portions of motion after the arrival of the stopping phase $\mathrm{S}_{2}$ of the horizontal component $\mathrm{N75E}$ and S33E at $\mathrm{CH} \$ 5,8,12$. Similarity of the wave forms among these stations is clearly visible [see displacement components of N75E in Figures 3(a), 4(a) and 5(a)]. These waves suffer dispersion as they travel toward the further stations (e.g. $\mathrm{CH} \# 12$ ). The apparent rate of dispersion, estimated for different episodes of the recorded Love waves, indicates that dispersion is more rapid for the waves which are recorded within a few seconds (e.g. $5 \mathrm{~s}$ ) after arrival of the $S_{2}$ phases [see the $A B$ intervals shown on displacement N75E in Figures 3(a), 4(a) and 5(a)] than for those which arrived later.

The N65E component of $\mathrm{CH} \# 2$ also recorded the Love waves [see Figure 2(a)]. The amplitudes are, in general, comparable with the amplitudes of the corresponding waves recorded at $\mathrm{CH} \sharp 5,8,12$.

It is interesting to note that the amplitudes of Love waves recorded at Temblor are considerably smaller than the amplitudes of those recorded at $\mathrm{CH} \$ 5,8,12$. The crust on the north-eastern side of the fault has more competent rocks and the upper crustal layers have smaller seismic velocity constants compared to those on the south-western side of the fault. These differences are perhaps responsible for the reduction of the amplitudes of Love waves at Temblor (on the north-western side of the fault). 
The vertical displacement at $\mathrm{CH} \# 5,8,12$ [see Figures 3(a), 4(a) and 5(a)] shows that Rayleigh waves have shorter periods than the corresponding Love waves recorded on the horizontal components. On the vertical component at $\mathrm{CH} \# 2$, the Rayleigh waves are superimposed as a single harmonic wave with a period of about $10 \mathrm{~s}$.

It is interesting to note [see Figures 2(a) to 6(a)] that Rayleigh waves at $C H \sharp 2,5,8,12$ are noticeably less energetic than Love waves. By comparison, the recorded Rayleigh waves at Temblor seem to carry more energy than Love waves.

\section{CONCLUSIONS}

Velocity and displacement traces integrated from the corresponding recorded accelerograms of the Parkfield earthquake of 1966 give important information on the properties of strong ground motion near to a rupturing fault. A double-couple right-lateral strike-slip mechanism (along the San Andreas fault) is compatible with the S-waves originating from the hypocentre.

The high energy arrivals observed on velocity traces at $\mathrm{CH} \# 2,5,8$ and Temblor (these arrivals also correspond to high amplitudes on the accelerograms) are interpreted as S-waves originating at the termination of the rupture towards the south-east of the San Andreas fault. Based on the reversed polarity of these waves, compared to those of hypocentral S-waves observed on the N57E component of displacement at $\mathrm{CH} \sharp 2,5,8$, 12 , the rupture termination was probably established by a double-couple left-lateral mechanism (stopping phase).

From the overall distribution of aftershocks and also from particle velocity diagrams of the stopping phases in the horizontal plane, the rupture seemed to terminate within $10 \mathrm{~km}$ north-west of $\mathrm{CH} \# 2$ (rupture length of about 20-28 km) at two possible depths of about 4 or $8 \mathrm{~km}$. For a depth of about $4 \mathrm{~km}$, rupture velocities of $3.1 \pm 0.5$ and $2.5 \pm 0.1 \mathrm{~km} / \mathrm{s}$ were estimated for two extreme rupture lengths of 28 and $20 \mathrm{~km}$, respectively. For a depth of $8 \mathrm{~km}$, the estimated rupture velocities are $3 \cdot 1 \pm 0.3$ and $2.4 \pm 0 \cdot 1 \mathrm{~km} / \mathrm{s}$. The evidence gives a preferred length of fault rupture of about $20 \mathrm{~km}$.

Love waves were more excited at the south-western than the north-eastern side of the fault. Rayleigh waves recorded at $\mathrm{CH} \# 2,5,8,12$ were less energetic than Love waves, whereas Rayleigh waves recorded at Temblor seemed to carry more energy than the Love waves.

\section{ACKNOWLEDGEMENTS}

I gratefully acknowledge Dr. Bruce A. Bolt, who provided the original stimulus for this research as well as valuable criticism and suggestions throughout its course. This work has been supported by the National Science Foundation Grant AEN 74-21548, and Seismographic Station of the University of California, Berkeley.

During the course of this work I was on educational leave from the Department of Geophysics, Ferdowsi University, Mashad, Iran. The financial support of Ferdowsi University and Iran's Ministry of Sciences and Higher Education is gratefully recognized.

\section{REFERENCES}

1. F. Aki, 'Seismic displacement near a fault', J. Geophys. Res. 73, 5359-5376 (1968).

2. N. A. Haskell, 'Elastic displacements in the near-field of a propagating fault', Bull. Seism. Soc. Am. 59, 865-908 (1969).

3. M. D. Trifunac and J. Brune, 'Complexity of energy release during the Imperial Valley, California, earthquake of 1940', Bull. Seism. Soc. Am. 60, 137-160 (1970).

4. B. A. Bolt, 'San Fernando rupture mechanism and the Pacoima strong motion record', Bull. Seism. Soc. Am. 62, 1053-1061 (1972),

S. D. M. Boore and M. D. Zoback, 'Two-dimensional kinematic fault modeling of the Pacoima dam strong-motion recordings of the February 9, 1971 San Fernando earthquake', Bull. Seism. Soc. Am. 64, 555-570 (1974).

6. M. D. Trifunac and F. E. Udwadia, 'Parkfield, California, earthquake of June 27, 1966: a three-dimensional moving dislocation', Bull. Seism. Soc. Am. 64, $511-533$ (1974).

7. T. C. Hanks, 'The faulting mechanism of the San Fernando earthquake', J. Geophys. Res. 79, 1215-1229 (1974).

8. V. V. Bertero, S. A. Mahin and R. A. Herrera, 'Aseismic design implications of near fault San Fernando Earthquake records', Earthqu. Eng. Struct. Dyn. 6, 31-42 (1978).

9. T. V. McEvilly, 'Preliminary seismic data, June-July, 1966 in Parkfield earthquake of June 27-29, 1966, Monterey and San Louis Obispo counties, California-preliminary report', Bull. Seism. Soc. Am. 56, 967-971 (1966). 
10. J. P. Eaton, M. E. O'Neill and J. N. Murdock, 'Aftershocks of the 1966 Parkfield-Cholame, California, earthquake: a detailed study', Bull. Seism. Soc. Am. 60, 1151-1197 (1970).

11. C. R. Allen and S. W. Smith, 'Parkfield earthquake of June 27-29, 1966, pre-earthquake and post-earthquake surficial displacement', Bull. Seism. Soc. Am. 56, 955-967 (1966).

12. R. E. Wallace and E. F. Roth, 'The Parkfield-Cholame, California earthquakes of June-August, 1966-rates and patterns of progressive deformation', U.S. Geol. Prof. Paper 579, 23-39 (1967).

13. T. V. McEvilly, W. H. Bakun and K. B. Casaday, 'The Parkfield, California, earthquakes of 1966', Bull. Seism. Soc. Am. 57, 1221-1244 (1967).

14. G. F. Murray, 'Note on strong motion records from the June 1966 Parkfield, California, earthquake sequence', Bull. Seism. Soc. Am. 57, 1259-1266 (1967).

15. J. P. Eaton, 'The Parkfield-Cholame, California, earthquakes of June-August 1966; instrumental seismic studies', U.S. Geol. Surv. Prof. Paper 579 (1967).

16. J. Filson and T. V. McEvilly, 'Love-wave spectra and the mechanism of the 1966 Parkfield sequence', Bull. Seism. Soc. Am. 57, 1245-1257 (1967).

17. C. H. Scholz M. Wyss and S. W. Smith, 'Seismic and aseismic slip on the San Andreas fault', J. Geophys. Res, 74, 2049-2069 (1969).

18. T. Anderson, 'A model source-time function for the Parkfield, California, earthquake (Abstract)', 68th Ann. Nat. Meeting Seismological Soc. Am., Golden, Colorado (1973).

19. Y. B. Tsai and H. J. Patton, 'Interpretation of the strong-motion earthquake accelerograms using a moving dislocation model: the Parkfield, California, earthquake of June 28, 1966 (Abstract)', 68th Ann. Nat. Meeting Seismological Soc. Am., Golden, Colorado (1973).

20. J. N. Brune, 'Tectonic stress and the spectra of seismic shear waves from earthquakes', J. Geophys. Res. 75, 4997-5009 (1970).

21. J. C. Savage, 'The effect of rupture velocity upon seismic first motions', Bull. Seism. Soc. Am. 55, 263-275 (1965).

22. J. C. Savage, 'The stopping phase on seismograms', Bull. Seism. Soc. Am. 55, 47-58 (1965). 